\title{
MICROSTRUCTURE EVOLUTION AND STATISTICAL ANALYSIS OF Al/Cu FRICTION-STIR SPOT WELDS
}

\author{
RAZVOJ MIKROSTRUKTURE IN STATISTIČNA ANALIZA \\ VRTILNO-TORNIH TOČKASTIH ZVAROV Al/Cu
}

\author{
Mukuna Patrick Mubiayi ${ }^{1}$, Esther Titilayo Akinlabi', \\ Mamookho Elizabeth Makhatha ${ }^{2}$ \\ ${ }^{1}$ University of Johannesburg, Department of Mechanical Engineering Science, Auckland Park Kingsway Campus, \\ 2006 Johannesburg, South Africa
${ }^{2}$ University of Johannesburg, Department of Metallurgy, School of Mining, Metallurgy and Chemical Engineering, Doornfontein Campus, \\ 2028 Doornfontein, South Africa \\ patrickmubiayi@gmail.com
}

Prejem rokopisa - received: 2016-11-18; sprejem za objavo - accepted for publication: 2017-03-16

doi: $10.17222 /$ mit. 2016.320

\begin{abstract}
In this paper, friction-stir spot welding (FSSW) is performed on $3 \mathrm{~mm}$ thick AA1060 and C11000 using different process parameters and tool geometries. The microstructure- and the microhardness-profile analyses were conducted and the probability distribution function (PDF) of the obtained microhardness values was determined. Optical images showed a good material mixing in most of the spot welds produced, whereas the energy-dispersive-spectroscopy (EDS) analysis showed the presence of intermetallic compounds. Microhardness results revealed that process parameters and tool geometries have significant effects on the distribution of microhardness values in different locations of the produced spot welds. Furthermore, goodness-of-fit values showed that most of the $R^{2}$ values ranged between 0.8842 and 0.9999 , which indicated how well the model fits with the experimental data. On the other hand, the residuals comprised positive and negative runs which also indicated the existence of a certain correlation with the experimentation.

Keywords: aluminium, copper, friction-stir spot welding, statistical analysis
\end{abstract}

V prispevku je predstavljeno vrtilno-torno točkovno varjenje (angl. FSSW) na 3 mm debeli pločevini AA1060 in C11000 z uporabo različnih procesnih parametrov in različno geometrijo orodij. Izvedene so bile analize profila mikrostrukture in mikrotrdote in določena je bila porazdelitvena funkcija verjetnosti za dobljene vrednosti mikrotrdote. Posnetki so pokazali dobro mešanje materiala na večini izdelanih točkovnih zvarov, medtem ko je EDS-analiza pokazala prisotnost intermetalnih spojin. Meritve mikrotrdote so pokazale, da imajo procesni parametri in geometrija orodij pomemben vpliv na porazdelitev mikrotrdote glede na različne lokacije izdelanih točkovnih zvarov. Nadalje je serija opazovanj oz. ocena pokazala, da je večina $\mathrm{R} 2$ vrednosti rangiranih med 0,8842 in 0,9999 . To potrjuje, da se model dobro ujema z eksperimentalnimi podatki. Po drugi strani pa razlika med pozitivnimi in negativnimi cikli kaže na obstoj določene korelacije s preizkušanjem.

Ključne besede: aluminij, baker, vrtilno-torno točkovno varjenje, statistična analiza

\section{INTRODUCTION}

Friction-stir welding (FSW) is a fairly new solid-state joining technique created and patented by The Welding Institute (TWI) in 1991 for butt and lap welding of ferrous and non-ferrous metals and plastics. ${ }^{1}$ Friction-stir spot welding (FSSW) is a novel variant of linear friction-stir welding (FSW) used for spot-welding applications. ${ }^{2}$ The FSSW process uses a non-consumable rotating tool which is plunged into the workpieces to be welded. Before attaining the selected plunge depth, the rotating tool is held at the same position for a fixed time, which is defined as the dwell time. Consequently, the rotating tool is withdrawn from the welded joint, leaving a solid-phase friction-stir spot weld behind. Throughout the FSSW process, the tool penetration depth and the

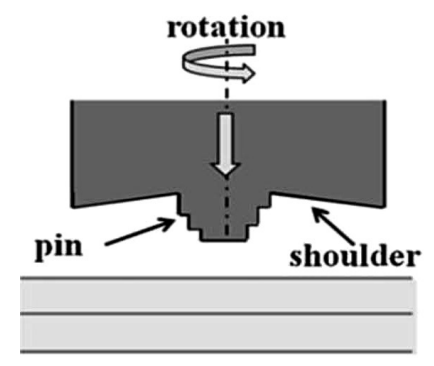

Plunge segment

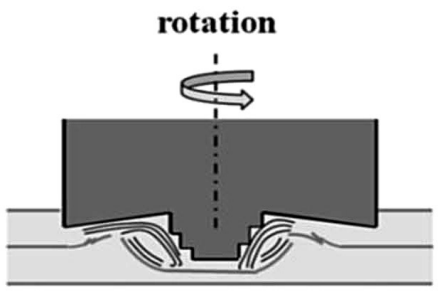

Stir segment

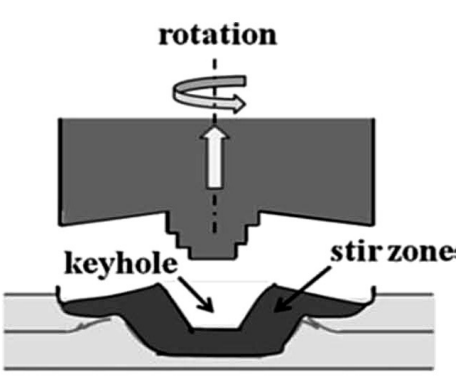

Retract segment

Figure 1: Schematic diagram of the friction-stir spot-welding process ${ }^{3}$ 
dwell time fundamentally determine the heat generation, material plasticization around the tool's pin, weld geometry and, hence, the mechanical properties of the welded joint. ${ }^{2}$ Figure 1 depicts a schematic illustration of the FSSW technique.

It should be noted that the FSSW process uses a non-consumable tool, which is similar to the FSW tool. ${ }^{4}$ The shoulder produces the frictional heat, whereas the pin creates the material flow between the work sheets. ${ }^{2,3}$ In addition to the tool, the other parameters involved in FSSW include the tool rotation speed, the tool plunge depth and the tool dwell time. These parameters have an effect on the strength, the surface texture of the welded joints $^{2}$ and the existence of weld defects. ${ }^{3}$

A typical cross-section of a friction-stir spot weld displays five different structures including the parent material (PM), the heat-affected zone (HAZ), the thermomechanically affected zone (TMAZ), the stir zone (SZ) and the hook. ${ }^{2}$

Friction-stir welding (FSW) and friction-stir spot welding (FSSW) of aluminium and copper have thus far not been fully investigated due to the huge difference between their melting temperatures and the high chemical affinity of both materials which facilitate the formation of brittle intermetallic $\mathrm{Al} / \mathrm{Cu}$ phases. ${ }^{6-18}$ Vickers hardness measurement is a common technique used to characterise the hardness of materials and it was reported that the presence of intermetallics affects the hardness values of the produced FS welds and FSS welds. ${ }^{11,17}$ On the other hand, statistical analyses of $\mathrm{Al} / \mathrm{Cu}$ friction-stir welds and spot welds have not been well researched. S. Akinlabi and E. T. Akinlabi ${ }^{19}$ conducted statistical analyses on the data obtained from dissimilar friction-stir butt welds of aluminium (AA5754) and copper (C11000) to understand the link between the process parameters and the properties of the resulting welds. They concluded that the downward vertical force has a significant effect on the ultimate tensile strength (UTS) of the produced welds. A robust relationship between the electrical resistivity and the heat input into the welds was also observed. ${ }^{19}$

Statistical analyses evaluate the effects of process parameters on the properties of the produced spot welds and establish the relationships amongst the process parameters.

Therefore, in the current study, an effort was made to further understand the relationships between the process parameters and the microhardness profiles of FSSW welds between copper and aluminium using the probability distribution function (PDF). Furthermore, the microstructure and the chemical analyses of the produced spot welds were also studied.

\section{MATERIALS AND WELDING PARAMETERS}

In this study, AA1060 and C11000 base materials with dimensions of $3 \mathrm{~mm}$ thickness, $600 \mathrm{~mm}$ length and
$120 \mathrm{~mm}$ width were friction-stir spot lap welded. The chemical compositions of the two parent materials were determined using a spectrometer. The chemical composition of the aluminium sheet is as follows: $0.058 \%$ mass fraction of $\mathrm{Si}, 0.481 \%$ mass fraction of $\mathrm{Fe}$, $0.011 \%$ mass fraction of $\mathrm{Ga}, 0.05 \%$ mass fraction of other elements and the rest is Al. The chemical composition of the copper sheet is: $0.137 \%$ mass fraction of $\mathrm{Zn},<0.1 \%$ mass fractions of $\mathrm{Pb}, 0.02 \%$ mass fraction of $\mathrm{Ni}, 0.023 \%$ mass fraction of $\mathrm{Al}, 0.012 \%$ mass fraction of $\mathrm{Co}, 0.077 \%$ mass fraction of $\mathrm{B}, 0.036 \%$ mass fraction of $\mathrm{Sb}, 0.043 \%$ mass fraction of $\mathrm{Nb},<0.492 \%$ mass fraction of other elements and the rest is $\mathrm{Cu}$.

The sheets were friction-stir spot welded in a $30 \mathrm{~mm}$ overlap configuration. The spot welds were produced at the eNtsa of Nelson Mandela Metropolitan University, Port Elizabeth, South Africa using an MTS PDS I-Stir. The tool material used was H13 tool steel hardened to 50-52 HRC with a $4 \mathrm{~mm}$ tool pin, $5 \mathrm{~mm}$ tool diameter and $15 \mathrm{~mm}$ tool shoulder. The friction-stir spot welds were produced at rotational speeds of $800 \mathrm{~min}^{-1}$ and $1200 \mathrm{~min}^{-1}$, the tool-shoulder-plunge depths employed were $0.5 \mathrm{~mm}$ and $1 \mathrm{~mm}$ at a constant dwell time of $10 \mathrm{~s}$. The two different tool profiles used in the current study were flat pin/flat shoulder and conical pin/concave shoulder tool, designated as FPS and CCS, respectively. The produced welds were designated as XX_XX_XX with the first part describing the tool geometry, the second part indicating the rotational speed and the third part indicating the shoulder plunge depth.

The weld samples were sectioned using wire electrical discharge machining (WEDM), grinded and polished, mounted and prepared, using the ASTM standard metallographic procedure and ASTM Standard E3-11.20

A solution of $\mathrm{FeCl}_{3}(10 \mathrm{~g})+\mathrm{HCl}(6 \mathrm{~mL})+$ ethanol $\left(\mathrm{C}_{2} \mathrm{H}_{5} \mathrm{OH}\right)(20 \mathrm{~mL})+\mathrm{H}_{2} \mathrm{O}(80 \mathrm{~mL})$ was used to etch the copper side of the spot welds, while the aluminium side was etched with $\mathrm{H}_{2} \mathrm{O}(190 \mathrm{~mL})+\mathrm{HNO}_{3}(5 \mathrm{~mL})+\mathrm{HCl}$ $(10 \mathrm{~mL})+\mathrm{HF}(2 \mathrm{~mL})$. The microstructure of the spot welds was studied using an optical microscope (Olympus BX51M) equipped with the Stream software. Scanning electron microscopy combined with energy dispersive spectroscopy (SEM/EDS) was used to further examine the microstructure and the chemical analyses, respectively. A TESCAN equipped with Oxford Instruments $\mathrm{X}$-Max was used for the SEM/EDS analyses. The Vickers microhardness was determined using a dia-

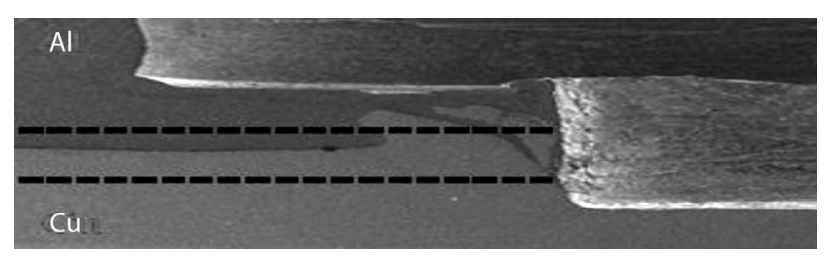

Figure 2: Representation of a spot weld with dashed lines illustrating the location of the microhardness-profile measurements 
M. P. MUBIAYI et al.: MICROSTRUCTURE EVOLUTION AND STATISTICAL ANALYSIS OF Al/Cu ...

mond-pyramid-indenter EMCO Test DuraScan tester. Two different locations on the spot welds were used, viz., the top and the bottom, as illustrated in Figure 2. The microhardness measurements were carried out from the keyhole for all the different parameters and tool geometries, to find the probability density function (PDF) of each one. The Matlab 2014 software program was used to determine the PDF.

\section{RESULTS AND DISCUSSION}

The microstructure of the friction-stir spot welds was studied using an optical microscope and the results are depicted in Figures 3 and 4.

Figure 3 illustrates the microstructures of the spot welds produced at: a) $800 \mathrm{~min}^{-1}$ and b) $1200 \mathrm{~min}^{-1}$, a $1 \mathrm{~mm}$ shoulder plunge depth using a flat pin and a flat shoulder tool. On the other hand, Figure 4 shows the microstructure of the spot weld produced at: a) $800 \mathrm{~min}^{-1}$ and b) $1200 \mathrm{~min}^{-1}$, a $0.5 \mathrm{~mm}$ shoulder plunge depth using a conical pin and a concave shoulder tool.

It can be seen in Figure 3a that there are a copper ring and a mixture of $\mathrm{Al} / \mathrm{Cu}$ particles in the stir zone. There is no palpable welding defect in the weld and copper is disseminated in this zone with different shapes. In the upper part of the joint, a large bulk of copper with
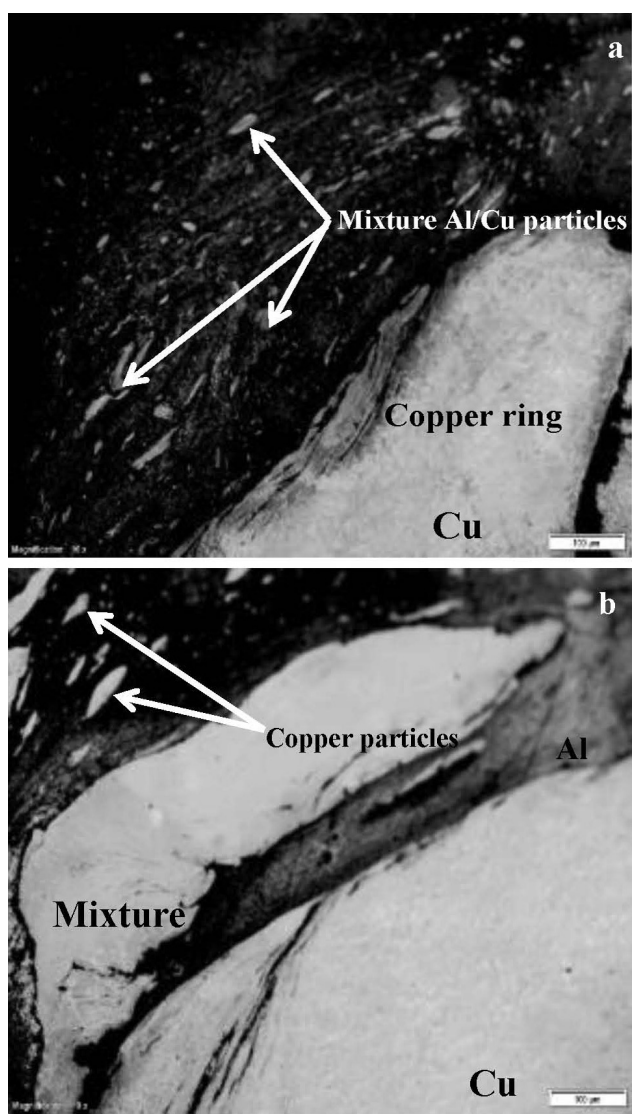

Figure 3: Optical microscope images showing the macrostructures of the joints at: a) $800 \mathrm{~min}^{-1}$ and b) $1200 \mathrm{~min}^{-1}, 1 \mathrm{~mm}$ shoulder plunge depth using a flat pin and flat shoulder tool
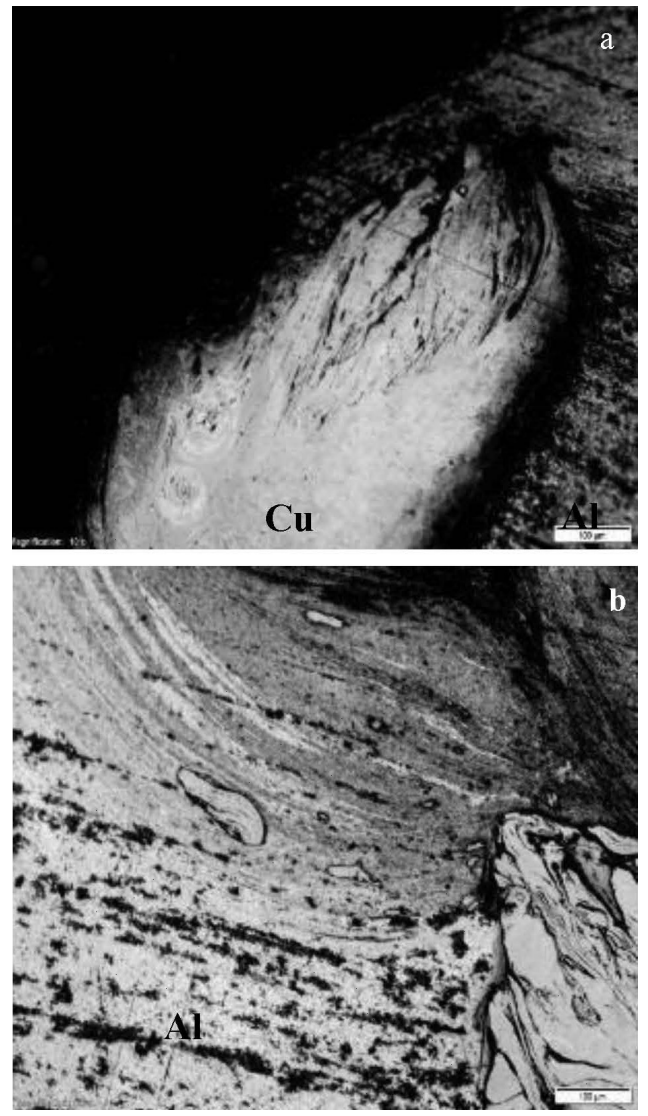

Figure 4: Optical microscope images showing the macrostructures of the joints at: a) $800 \mathrm{~min}^{-1}$ and b) $1200 \mathrm{~min}^{-1}, 0.5 \mathrm{~mm}$ shoulder plunge depth using a conical pin and concave shoulder tool

irregular shapes can be observed (Figure 3a). The tool pin was inserted in the aluminium plate and the copper ring extruded upward from the lower copper plate into the aluminium plate was observed. This was in agreement with the previous work. ${ }^{15}$

Additionally, the intermixing of copper and aluminium was not homogenous for different spot welds and different microstructures were formed in different regions of the welds. It was reported that the FSW of dissimilar materials is different from that of similar materials due to the formation of a complex, intercalated vortex-like and related flow pattern. ${ }^{21}$

In Figure 4b, a good interlaced structure can be seen. This is formed by aluminium and copper, thereby indicating that the two plates are bonded firmly in this region, which is composed of a lamellar structure of copper particles with a streamlined shape of aluminium strips. In this region, a few disseminated copper particles were also observed.

The energy-dispersive-spectrometry analyses at the selected points in the stir zone were recorded using SEM micrographs (Table 1). Intermetallic compounds were found in most of the produced welds. Two intermetallic compounds, viz., $\mathrm{Al}_{2} \mathrm{Cu}$ and $\mathrm{Al}_{3} \mathrm{Cu}_{4}$ were found in the weld produced at $1200 \mathrm{~min}^{-1}, 0.5 \mathrm{~mm}$ shoulder plunge 
M. P. MUBIAYI et al.: MICROSTRUCTURE EVOLUTION AND STATISTICAL ANALYSIS OF Al/Cu ...

Table 1 displays SEM micrographs and the EDS analysis of selected points on the produced friction-spot welds: a) (FFS_1200_0.5), b) (FFS_1200_1), c) (CCS_1200_0.5) and d) (CCS_1200_1).

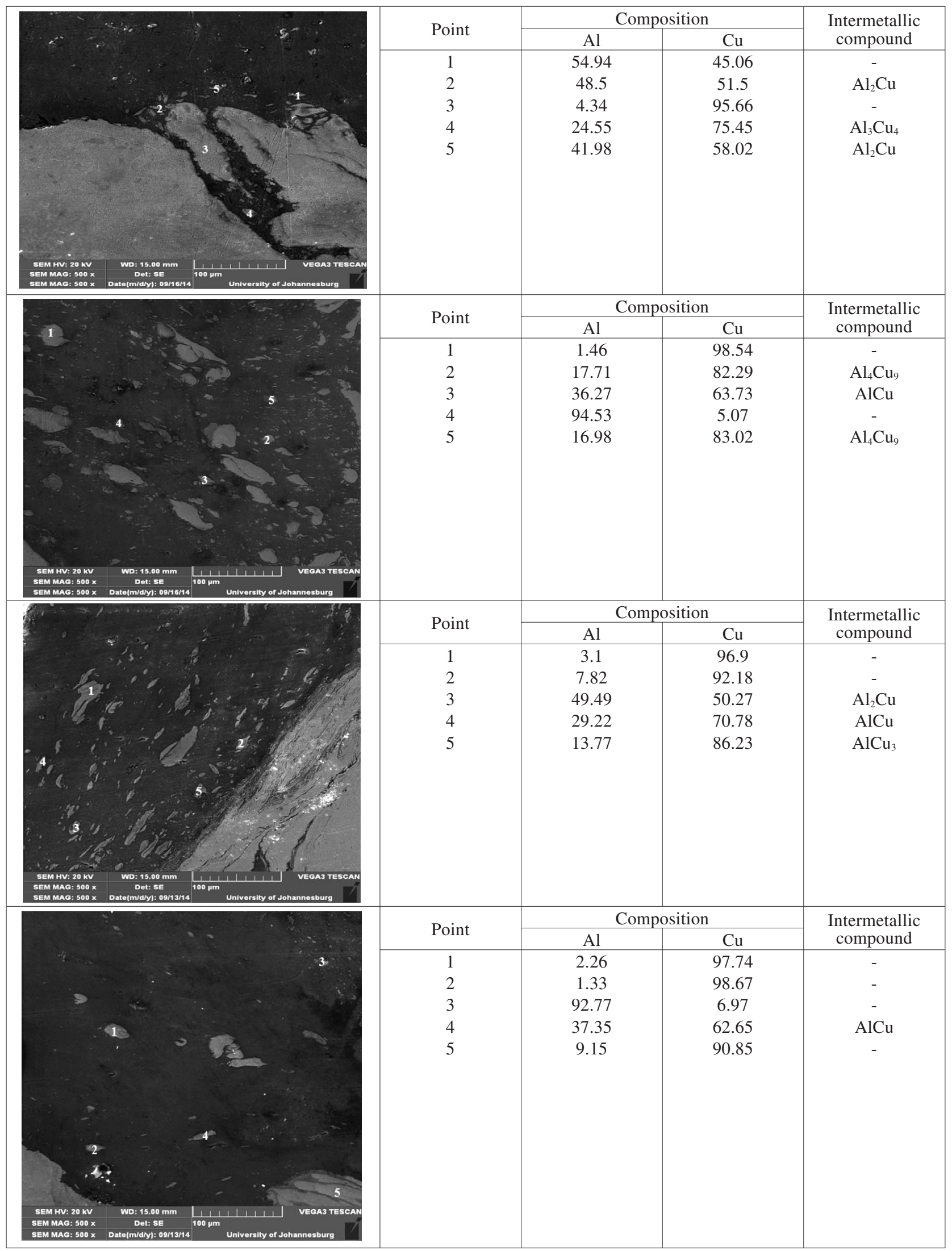


M. P. MUBIAYI et al.: MICROSTRUCTURE EVOLUTION AND STATISTICAL ANALYSIS OF Al/Cu ...
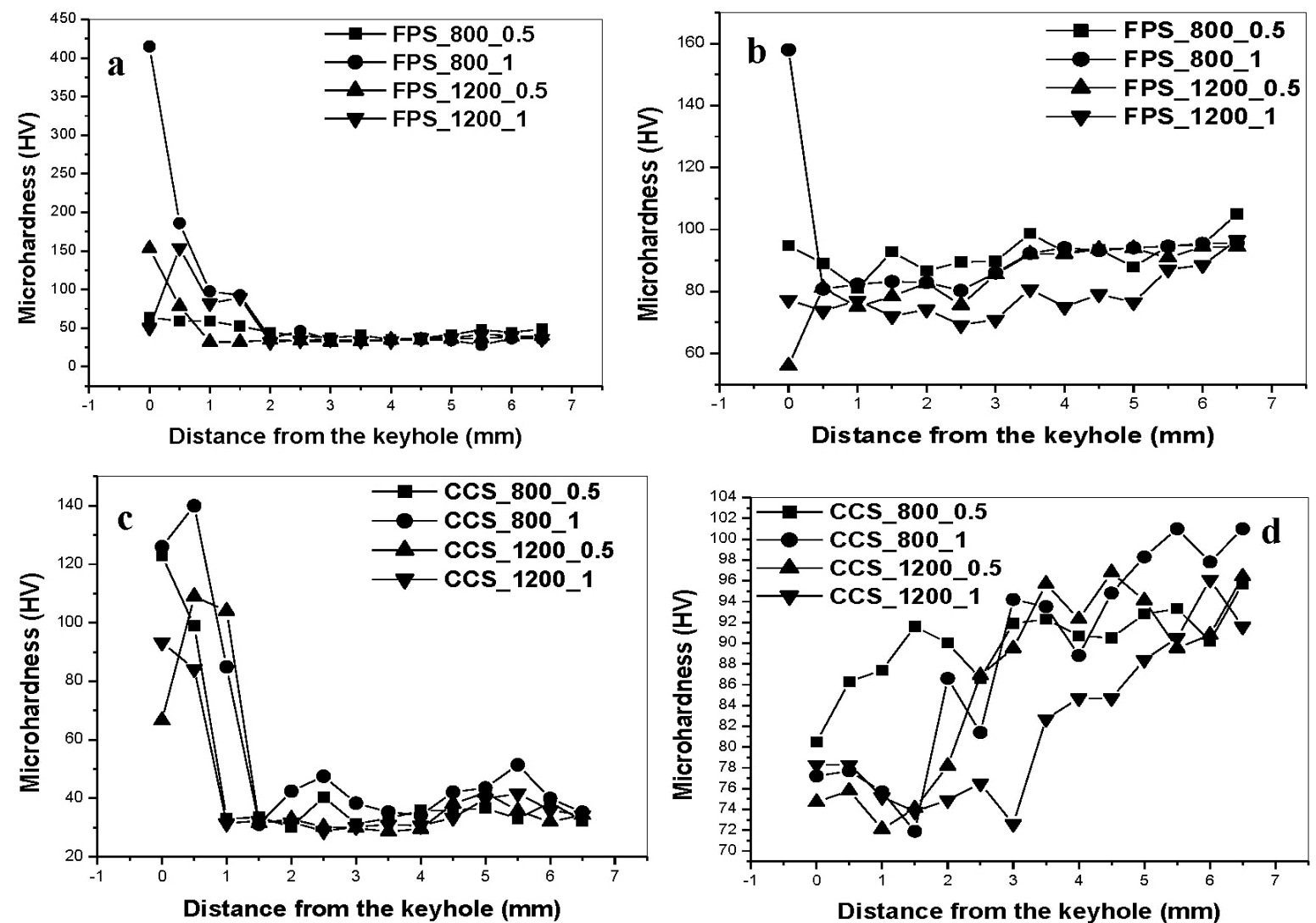

Figure 5: Microhardness distributions along the welds produced using different tools and process parameters: a) flat pin/flat shoulder (FPS), top; b) bottom; c) conical pin/concave shoulder (CCS), top; d) bottom

depth, whereas the weld produced at $1200 \mathrm{~min}^{-1}$ and 1 mm shoulder plunge depth contained $\mathrm{Al}_{4} \mathrm{Cu}_{9}$ and $\mathrm{AlCu}$ intermetallic compounds. These intermetallics were found in the welds produced using a flat pin and flat shoulder tool. On the other hand, the spot welds produced using a conical pin and concave shoulder contained $\mathrm{Al}_{2} \mathrm{Cu}, \mathrm{AlCu}_{3}$ and $\mathrm{AlCu}$ intermetallic compounds. These intermetallic compounds were found in the weld produced at $1200 \mathrm{~min}^{-1}$ and $0.5 \mathrm{~mm}$ shoulder plunge depth. Only the $\mathrm{AlCu}$ intermetallic was found in the weld produced at $1200 \mathrm{~min}^{-1}$ and $1 \mathrm{~mm}$ shoulder plunge depth, but the concentration of this intermetallic compound was relatively small. It was reported that the presence of intermetallic compounds could affect the microhardness profile. ${ }^{17}$

Figure 5 (a, b, c and d) shows the microhardness values of the spot welds produced using a flat pin and a flat shoulder tool, or a conical pin and a concave shoulder at different process parameters. The microhardness values of the parent materials were in the range of 86.7-96.3 $\mathrm{HV}$ for $\mathrm{Cu}$ while for $\mathrm{Al}$, the range was between 34.6-40.3 HV. In all the samples, high microhardness values were recorded at the top, in the region close to the keyhole.
It was reported that all the mechanical tests are subject to large statistical variations, which should be evaluated. ${ }^{22}$

The probability distribution function (PDF) of the Vickers hardness was reported in the literature to correspond to the Gaussian (or normal) distribution ${ }^{23}$ and log-normal distribution. ${ }^{24}$ A. M. Hassan et al. ${ }^{25}$ studied the significance of the process parameters of friction-stir welding of aluminium-matrix composites to set the optimum level for each of these parameters and to further predict which responses are affected when using analyses of variance (ANOVA). ${ }^{25}$ The present study used the Matlab 2014a statistical toolbox to analyse the probability density function (PDF) of the obtained microhardness results. This was done to understand how different parameters and tool geometries affect the probability of obtaining specific microhardness values.

A probability density function (PDF) is a function that defines the relative possibility for a random variable to take on a given value. The probability of the random variable falling within a particular range $[a, b]$ of values is given with a finite integral of the PDF within that range $[a, b]$, Equation (1):

$$
p(x)=\int_{b}^{a} f(x, \mu, \sigma)=\int_{b}^{a} \frac{1}{\sqrt{2 \pi \sigma^{2}}} e^{-\frac{(x-\mu)^{2}}{2 \sigma^{2}}}
$$


M. P. MUBIAYI et al.: MICROSTRUCTURE EVOLUTION AND STATISTICAL ANALYSIS OF Al/Cu ...
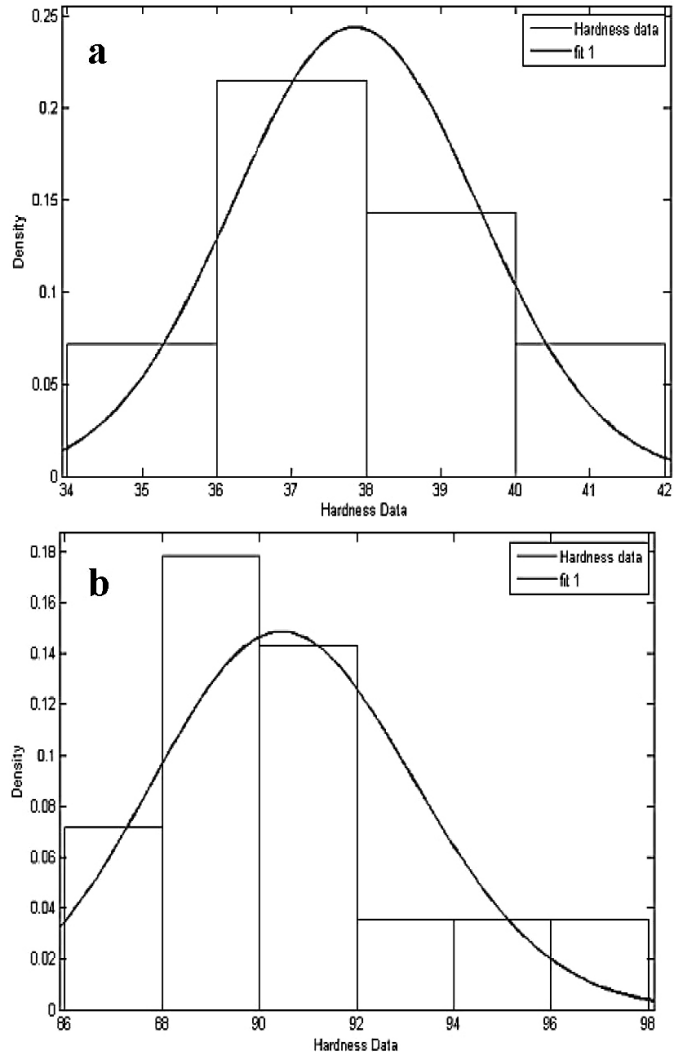

Figure 6: Depicting the microhardness PDF histograms of the parent materials: a) aluminium, b) copper
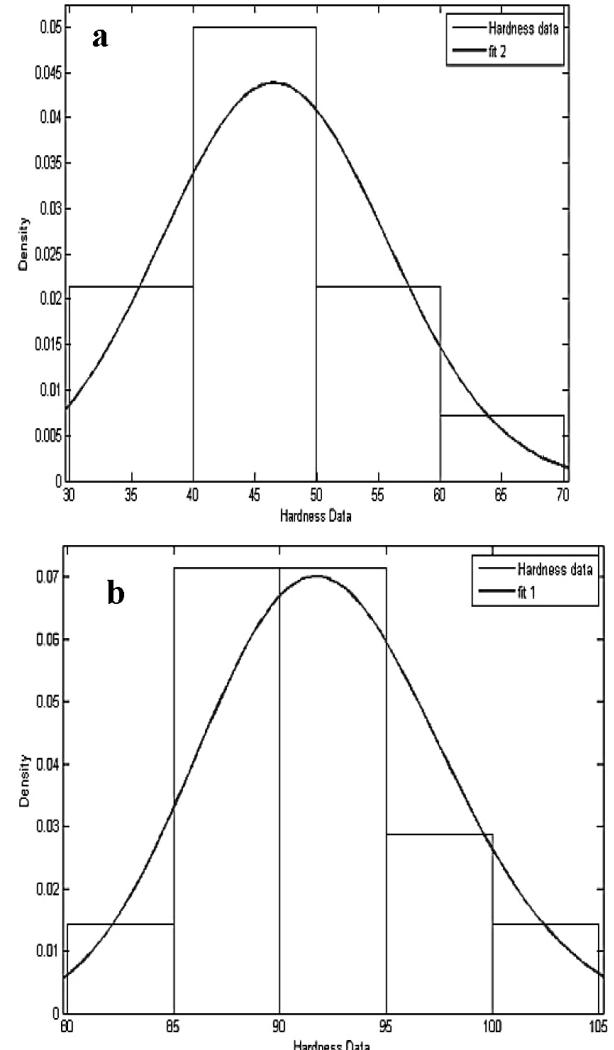

Figure 7: PDF histograms of the microhardness of FPS_800_0.5 spot weld: a) top and b) bottom where $\sigma$ is the standard deviation, $\sigma^{2}$ is the variance and $\mu$ is the mean.

It is given by the area under the density function, nonetheless above the horizontal axis and in between the lowest and highest values of the range. The probability density function is a non-negative value and its integral over the entire space is equal to one.

PDF histograms of the microhardness and their fits for the parent materials, namely, aluminium and copper, are depicted in Figures $\mathbf{6 a}$ and $\mathbf{7 b}$, respectively. The PDFs of the top and bottom hardness measurements were investigated, Figures $\mathbf{7 a}$ and $\mathbf{7 b}$ depict the PDF histograms of the microhardness for the weld produced at $800 \mathrm{~min}^{-1}, 0.5 \mathrm{~mm}$ shoulder plunge depth, using a flat pin and a flat shoulder tool.

It can be seen that the probability of having the microhardness values between 40 and $45 \mathrm{HV}$ is high in the histogram, as shown in Figure 7a, which represents the microhardness measured at the top of the spot weld. This corresponds mostly to the microhardness of the aluminium parent material, whereas the possibility of getting high microhardness values between 50 and 60 $\mathrm{HV}$ is low.

On the other hand, the PDF of the bottom measurement (Figure $\mathbf{7 b}$ ) shows that there is a high possibility of getting microhardness values between 85 and $95 \mathrm{HV}$. This corresponds to the microhardness of the copperparent sheets, while the microhardness values between
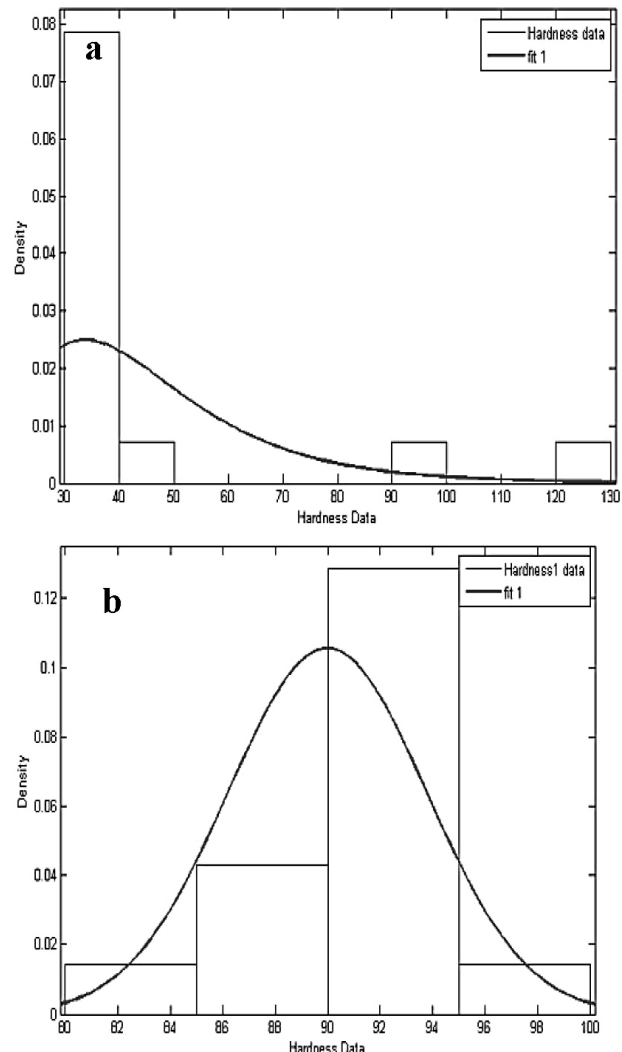

Figure 8: PDF histogram of the microhardness of CCS_800_0.5 spot weld: a) top and b) bottom 
M. P. MUBIAYI et al.: MICROSTRUCTURE EVOLUTION AND STATISTICAL ANALYSIS OF Al/Cu ...

$100 \mathrm{HV}$ and $105 \mathrm{HV}$ are likely to show a lower possibility of being obtained when using the same process parameters as those used in this research work. The possibility of having higher microhardness values compared to the values of the parent materials in the two different sheets (copper and aluminium) was observed to be due to the presence of a mixture of copper and aluminium in the vicinity of the keyhole. Additionally, Figure 8 depicts a PDF histogram of the microhardness measurements ((a) top and (b) bottom) for the weld produced at $800 \mathrm{~min}^{-1}, 0.5 \mathrm{~mm}$ shoulder plunge depth, using a conical pin and a concave shoulder.

The results show that there is a higher possibility for obtaining microhardness values between $3050 \mathrm{HV}$ and $50 \mathrm{HV}$, whereas the possibility for high values between 120 and $130 \mathrm{HV}$ is low (Figure 8a). The trend for the bottom area (Figure 8b) is similar to the one discussed above for the PDF of the bottom microhardness obtained using a flat pin and a flat shoulder.

Moreover, when the rotational speed of $1200 \mathrm{~min}^{-1}$ is increased, the possibility of getting high microhardness values ranging between 100-110 HV and 90-100 HV increases for the top area of the spot weld produced using a conical pin and a concave shoulder, and for the top and bottom microhardness values, respectively. It can be seen that the rotational speed and the tool geometry may influence the possibility of different probability distributions.

The model shows that, in order to get the probability in a specific region, the integral of the PDF for the region of interest need to be computed. The PDF found in the current research work is a normal distribution (called a Gaussian distribution as well). In order to get any probability, we can compute the finite integral of the normal distribution equation (1).

The goodness of fit and the residuals were also analysed. The results show that most of the $R^{2}$ values range between 0.8842 and 0.9999 , which is an indication of how well the model fits with the experimental data shown in Table 2.

Table 2: $R^{2}$ and adjusted $R^{2}$ of the welds produced using a flat pin/flat shoulder tool and conical pin/concave shoulder tool for the microhardness measured on the top and at the bottom

\begin{tabular}{|l|c|c|}
\hline \multicolumn{1}{|c|}{ Sample ID } & $R^{2}$ square & $R^{2}$ square \\
\hline FPS_800_0.5 & 0.9896 & 0.8842 \\
\hline FPS_800_1 & 0.9996 & 0.9999 \\
\hline FPS_1200_0.5 & 0.9999 & 0.9937 \\
\hline FPS_1200_1 & 0.9993 & 0.9298 \\
\hline CCS_800_0.5 & 0.9924 & 0.9818 \\
\hline CCS_800_1 & 0.9976 & 0.9424 \\
\hline CCS_1200_0.5 & 0.9893 & 0.987 \\
\hline CCS_1200_1 & 0.9997 & 0.9866 \\
\hline
\end{tabular}

Figures 9a to $\mathbf{9 b}$ depict the goodness of fit and the residuals for the weld produced at $1200 \mathrm{~min}^{-1}, 1 \mathrm{~mm}$ shoulder plunge depth, using a flat pin and a flat shoulder (the top-microhardness measurement). In
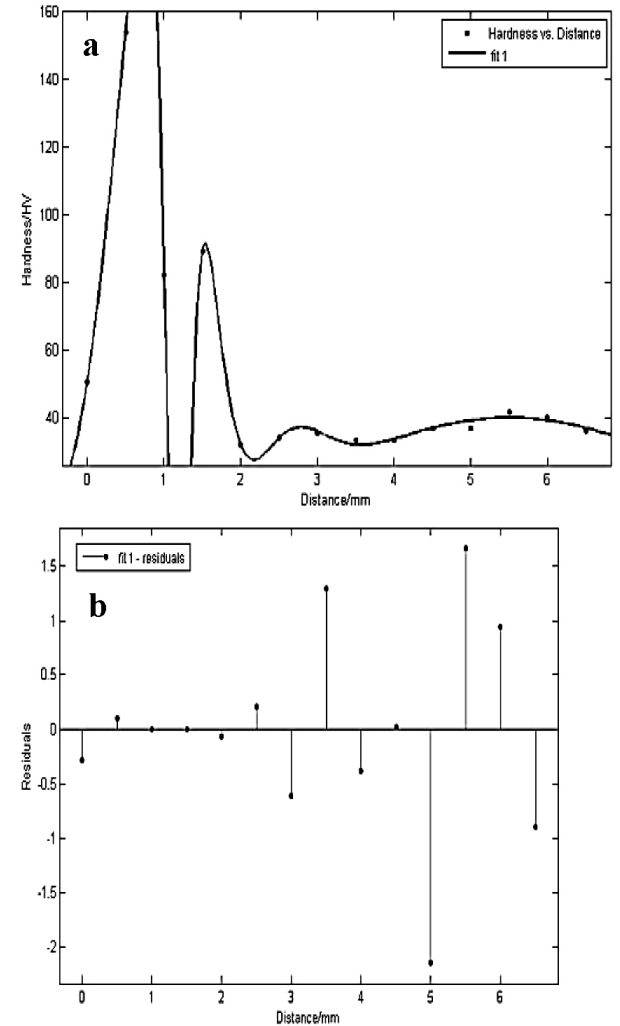

Figure 9: a) goodness of fit and b) the residuals for the spot weld produced at $1200 \mathrm{~min}^{-1}, 1 \mathrm{~mm}$ shoulder plunge depth, using a flat pin and a flat shoulder (top-microhardness measurements)
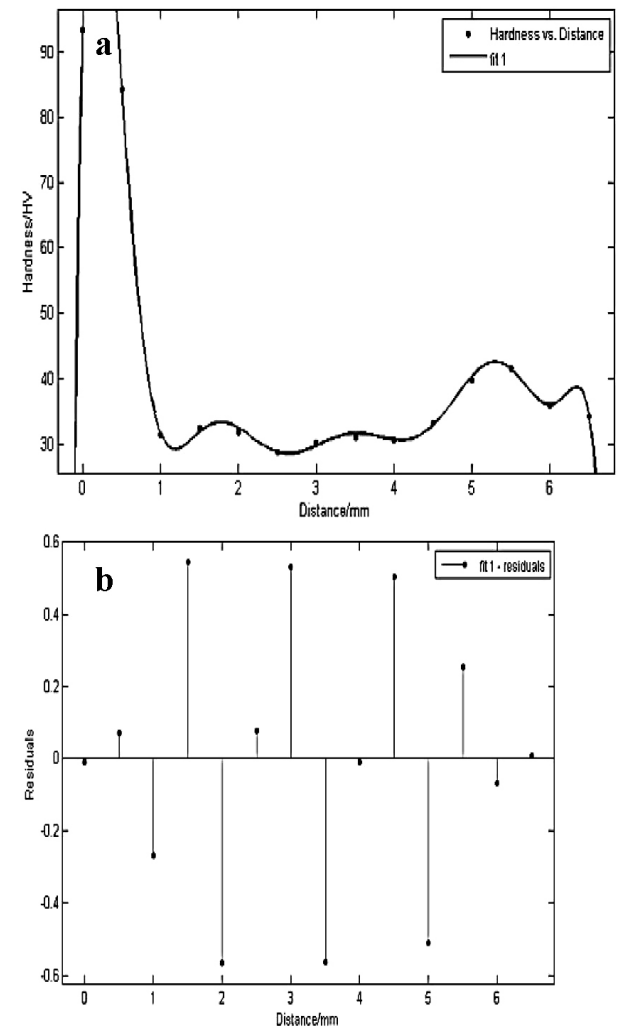

Figure 10: a) goodness of fit and b) the residuals for the spot weld produced at $1200 \mathrm{~min}^{-1}, 1 \mathrm{~mm}$ shoulder plunge depth, using a conical pin and a concave shoulder (top-microhardness measurements) 
addition, Figures 10a to $\mathbf{1 0 b}$ depict the goodness of fit and the residuals for the weld produced at $1200 \mathrm{~min}^{-1}, 1$ $\mathrm{mm}$ shoulder plunge depth, using a conical pin and a concave shoulder (the top-microhardness measurement). Besides the $R^{2}$ values, the residual analysis was also employed in the study in order to check the adequacy of the models. Figures $\mathbf{9 b}$ and $\mathbf{1 0 b}$ show the residual plots for the microhardness values obtained at the top, using a flat pin/flat shoulder and a conical pin/concave shoulder, using the $1200 \mathrm{~min}^{-1}$ speed and $1 \mathrm{~mm}$ shoulder plunge depth, respectively. It was reported that the tendencies to have runs of positive and negative residuals indicate the existence of a certain correlation with the experimentation. $^{26}$

Tables 3 and $\mathbf{4}$ present the standard deviation, the variance and the mean obtained from the statistical analyses of the measured microhardness values for the two different positions, namely, the top and bottom of the spot welds produced with different tools and using different process parameters.

Table 3: Mean, variance, mu and sigma of the spot samples produced using a flat pin/flat shoulder tool and a conical pin/concave shoulder tool for the microhardness taken on the top

\begin{tabular}{|l|c|c|c|c|}
\hline \multicolumn{1}{|c|}{ Sample ID } & Mean & $\sigma^{2}$ & $\mu$ & $\sigma$ \\
\hline FPS_800_0.5 & 46.543 & 82.8442 & 46.5429 & 9.102 \\
\hline FPS_800_1 & 75.099 & 4994.97 & 4.00167 & 0.796 \\
\hline FPS_1200_0.5 & 45.121 & 441.806 & 3.71115 & 0.443 \\
\hline FPS_1200_1 & 51.731 & 672.845 & 3.83391 & 0.474 \\
\hline CCS_800_0.5 & 44.575 & 409.802 & 3.70341 & 0.433 \\
\hline CCS_800_1 & 55.887 & 813.763 & 3.90757 & 0.481 \\
\hline CCS_1200_0.5 & 45.453 & 482.889 & 3.71166 & 0.458 \\
\hline CCS_1200_1 & 40.942 & 248.04 & 3.64315 & 0.371 \\
\hline
\end{tabular}

Table 4: Mean, variance, mu and sigma of the spot samples produced using a flat pin/flat shoulder tool and a conical pin/concave shoulder tool for the microhardness taken at the bottom

\begin{tabular}{|l|c|c|c|c|}
\hline \multicolumn{1}{|c|}{ Sample ID } & Mean & $\sigma^{2}$ & $\mu$ & $\sigma$ \\
\hline FPS_800_0.5 & 92.234 & 32.7196 & 4.52241 & 0.062 \\
\hline FPS_800_1 & 84.7 & 119.974 & 84.7 & 10.95 \\
\hline FPS_1200_0.5 & 84.7 & 119.974 & 84.7 & 10.95 \\
\hline FPS_1200_1 & 78.429 & 58.0637 & 78.4286 & 7.62 \\
\hline CCS_800_0.5 & 89.986 & 14.2859 & 89.9857 & 3.78 \\
\hline CCS_800_1 & 88.564 & 102.307 & 88.5643 & 10.11 \\
\hline CCS_1200_0.5 & 86.252 & 89.6604 & 4.45128 & 0.109 \\
\hline CCS_1200_1 & 82.043 & 54.8519 & 4.40318 & 0.09 \\
\hline
\end{tabular}

It should be noted that the mean is equal to $\mu$ if the distribution is normal. It can be seen that in some cases in the current work $\mu$ and the mean have different values, which shows that the distributions in some of the analyses were not normal. The standard deviation $\sigma$ should be close to zero, but in the current work, the value of the standard deviation is not close to zero in some of the cases. This shows that the microhardness values are not close to the expected values and this could be due to the microhardness values measured in different locations of the weld samples, far apart from each other.
This was further suspected due to the presence of intermetallics, which could have been the cause of the high microhardness values since intermetallics are invariably hard and brittle.

Each figure contains residuals versus the distance (the distance from the keyhole), taking into account the data and the constant variance of the residuals. In the plot of residuals versus distance, it is shown that the models are adequate to predict the responses in an acceptable manner.

\section{CONCLUSIONS}

According to the presented results, some conclusions can be drawn:

- The microstructure of the produced spot welds shows a good material mixing, the presence of a copper ring and a mixture of $\mathrm{Al} / \mathrm{Cu}$ particles present in the stir zone.

- The EDS analyses of the produced friction-stir spot welds exhibited the presence of intermetallic compounds, which are known to affect the microhardness.

- The microhardness values obtained at the top were high for all the samples and this was in the region close to the spot-weld keyhole. In addition, all the microhardness values obtained at the bottom of the samples, in the region close to the keyhole, have lower values, which were close to the average value of the copper base material. This occurred for all the spot welds produced using a conical pin and concave shoulder.

- The probability-density-function (PDF) histograms of the microhardness results revealed that the process parameters and the tool geometries have significant effects on the distribution of the microhardness values in different locations of the produced spot welds.

- Additionally, goodness-of-fit values were also analysed and these showed that most of the $R^{2}$ values ranged between 0.8842 and 0.9999 , which is an indication of how well the model fits with the produced experimental data.

\section{Acknowledgements}

The authors wish to acknowledge the financial support of the University of Johannesburg and the assistance from Mr. Riaan Brown (eNtsa at Nelson Mandela Metropolitan University).

\section{REFERENCES}

${ }^{1}$ W. M. Thomas, E. D. Nicholas, J. C. Needham, M. G. Murch, P. Temple-Smith, C. J. Dawes, International Patent No. PCT/GB92/ 02203, GB patent application No. 9125978.8, 1991

${ }^{2}$ H. Badarinarayan, Fundamentals of Friction Stir Spot Welding, PhD Thesis, 2009, Missouri 


\section{MATERIALI IN TEHNOLOGIJE/MATERIALS AND TECHNOLOGY (1967-2017) - 50 LET/50 YEARS}

\section{P. MUBIAYI et al.: MICROSTRUCTURE EVOLUTION AND STATISTICAL ANALYSIS OF Al/Cu ...}

${ }^{3}$ W. Yuan, R. S. Mishra, B. Carlson, R. Verma, R. K. Mishra, Material flow and microstructural evolution during friction stir spot welding of AZ31 magnesium alloy, Materials Science and Engineering, A 543 (2012), 200-209

${ }^{4}$ J. Podržaj, B. Jerman, D. Klobčar, Welding defects at friction stir welding, Metalurgija, 54 (2015) 2, 387-389

${ }^{5}$ J. M. Timothy, Friction Stir Welding of Commercially Available Superplastic Aluminium, PhD thesis, 2008, Department of Engineering and Design, Brunel University, Brunel

${ }^{6}$ J. Ouyang, E. Yarrapareddy, R. Kovacevic, Microstructural evolution in the friction stir welded 6061 aluminum alloy (T6-temper condition) to copper, Journal of Materials Processing Technology, 172 (2006), 110-122

${ }^{7}$ P. Liu, Q. Shi, W. Wang, X. Wang, Z. Zhang, Microstructure and XRD analysis of FSW joints for copper T2/aluminium 5A06 dissimilar materials, Materials Letters, 62 (2008), 4106-4108

${ }^{8}$ P. Xue, B. L. Xiao, D. R. Ni, Z. Y. Ma, Enhanced mechanical properties of friction stir welded dissimilar $\mathrm{Al}-\mathrm{Cu}$ joint by intermetallic compounds, Materials Science and Engineering A, 527 (2010), 5723-5727

${ }^{9}$ A. Esmaeili, M. K. Besharati Givi, H. R. Zareie Rajani, A metallurgical and mechanical study on dissimilar friction stir welding of aluminum 1050 to brass (CuZn30), Materials Science and Engineering, A 528 (2011), 7093-7102

${ }^{10}$ A. Abdollah-Zadeh, T. Saeid, B. Sazgari, Microstructural and mechanical properties of friction stir welded aluminum/copper lap joints, Journal of Alloys and Compounds, 460 (2008), 535-538

${ }^{11}$ E. T. Akinlabi, Characterisation of Dissimilar Friction Stir Welds between 5754 Aluminium Alloy and C11000 Copper, D-Tech thesis, Nelson Mandela Metropolitan University, South Africa, 2010

${ }^{12}$ M. N. Avettand-Fenoel, R. Taillard, G. Ji, D. Goran, Multiscale Study of Interfacial Intermetallic Compounds in a Dissimilar A 6082-T6/Cu Friction-Stir Weld, Metallurgical and Materials Transactions A, (2012), 4655-4666

${ }^{13}$ M. F. X Muthu, V. Jayabalan, Tool Travel Speed Effects on the Microstructure of Friction Stir Welded Aluminium - Copper Joints, Journal of Materials Processing Technology, 217 (2015), 105-113

${ }^{14}$ M. P. Mubiayi, E. T Akinlabi, Friction Stir Spot Welding between Copper and Aluminium: Microstructural Evolution, Proceedings of the International MultiConference of Engineers and Computer Scientists, Vol II, IMECS 2015, March 18-20, 2015, Hong Kong
${ }^{15}$ R. Heideman, C. Johnson, S. Kou, Metallurgical analysis of A1/Cu friction stir spot welding, Science and Technology of Welding and Joining, 15 (2010) 7, 597-604

${ }^{16}$ U. Özdemir, S. Sayer, Ç. Yeni, Bornova-Izmir, Effect of Pin Penetration Depth on the Mechanical Properties of Friction Stir Spot Welded Aluminum and Copper, Materials Testing in Joining Technology, 54 (2012) 4, 233-239

${ }^{17}$ M. Shiraly, M. Shamanian, M. R. Toroghinejad, M. Ahmadi Jazani, Effect of Tool Rotation Rate on Microstructure and Mechanical Behavior of Friction Stir Spot-Welded Al/Cu Composite, Journal of Materials Engineering and Performance, 23 (2014) 2, 413-420

${ }^{18}$ M. P. Mubiayi, E. T. Akinlabi, Evolving properties of friction stir spot welds between AA1060 and commercially pure copper C11000, Transactions of Nonferrous Metals Society of China, 26 (2016), 1852-1862

${ }^{19}$ E. T Akinlabi, S. A. Akinlabi, Friction stir welding of dissimilar materials - statistical analysis of the weld data, Proceedings of the International MultiConference of Engineers and Computer Scientists, 2012, 1368-1373

${ }^{20}$ ASTM Standard E3-11, Standard guide for preparation of metallographic specimens, ASTM International, West Conshohocken, PA, 2011, doi: 10.1520/E0003-11, www.astm.org

${ }^{21}$ L. E Murr, A Review of FSW Research on Dissimilar Metal and Alloy Systems, Journal of Materials Engineering and Performance, 8 (2010)19, 1071-108

${ }^{22}$ J. M. Schneider, M. Bigerelle, A. Iost, Statistical analysis of the Vickers hardness, Materials Science and Engineering, A 262 (1999), 256-263

${ }^{23}$ A. L. Yurkov, N. V. Jhuravleva, E. S. Lukin, Kinetic microhardness measurements of sialon-based ceramics, Journal of Materials Science, 29 (1994), 6551-6560

${ }^{24}$ I. Y. Yanchev, E. P. Trifonova, Analysis of microhardness data in Tlx ln 1-x Se, Journal of Materials Science, 30 (1995), 5576-5580

${ }^{25}$ A. M. Hassan, M. Almomani, T. Qasim, A. Ghaithan, Statistical analysis of some mechanical properties of friction stir welded aluminium matrix composite, Int. J. Experimental Design and Process Optimisation, 3 (2012)1, 91-109

${ }^{26}$ K. Palanikumar, R. Karthikeyan, Optimal machining conditions for turning of particulate metal matrix composites using Taguchi and response surface methodologies, Machining Science and Technology, 10 (2006) 4, 417-433 